\title{
A LIBERDADE ENQUANTO SÍNTESE DE OPOSTOS: TRANSCENDÊNCIA, ENGAJAMENTO E INSTITUCIONALIDADE
}

Manfredo Araújo de Oliveira*

SINTESE - Principiando com uma recuperação do legado da tradição, o texto pretende tratar, sistematicamente, da questão da liberdade como questão que emerge da própria experiência originária do ser humano como ser-no-mundo. A liberdade emerge num primeiro momento como a capacidade de transcendência de toda e qualquer facticidade; num segundo momento, como engajamento diante das inúmeras possibilidades e por fim, liberdade só é, verdadeiramente, efetiva enquanto mundo de instituições.

PALAVRAS-CHAVE - Liberdade. Reflexão.
ABSTRACT - By starting with the retrieval of the tradition's legacy, this article seeks to systematically deal with the question of freedom as it emerges out of the very originary experience of human being qua being-in-the-world. Freedom emerges, in a first moment, as the capacity for transcending every facticity. In a second moment, freedom appears as engagement (commitment) in the face of innumerable possibilities, and, finally, it proves truly effective qua world of institutions. KEY WORDS - Freedom. Reflection. Engagement (commitment). Institution.

Engajamento. Instituiçăo.

\section{O legado da tradição}

A questão da liberdade, de formas diferenciadas, acompanhou sempre a filosofia ocidental e isto porque ela emerge da própria experiência da vida do homem como ser-no-mundo: a experiência do ser inserido no mundo e interpelado a agir. O mundo é interpretado, no pensamento clássico, como um movimento eterno de forma circular, onde tudo se movimenta arrastado pelo motor imóvel, o centro do cosmo, puro pensamento de si mesmo. Todo ente é, em princípio, marcado por uma tendência natural que, em última instância, o empurra para o ser, naturalmente, perfeito e é isto que constitui sua bondade.' Este movimento eterno do cosmo é a referência, também, para a ação humana: o ser humano é bom, quando, através de uma deliberação sensata, descobre o verdadeiro caminho para

* Professor da Universidade Federal do Ceará (UFC).

Cf.: Anistóteles, Et. Nic., I, 1, 1094.

\begin{tabular}{|l|l|l|l|l|l|}
\hline VERITAS & Porto Alegre & v. 44 & n. 4 & Dezembro 1999 & p. 1019-1040 \\
\hline
\end{tabular}


a realização da ordem do todo em sua vida pessoal e social. ${ }^{2}$ Assim, ele é livre, quando realiza, em sua vida histórica, sua essência, que estabelece o lugar que ele ocupa no cosmo, a ordem imutável do real. ${ }^{3}$

O pensamento cristão provocou uma reviravolta na concepção do mundo e, conseqüentemente, na forma de levantar a questão da liberdade, pois, para ele, o fundamento, que sustenta toda a realidade não divina é o ato criador livre de Deus, o que significa dizer que a orientação do agir humano não se legitima mais, simplesmente, na ordem do cosmo, uma vez que esta ordem mesma perdeu sua evidência e necessidade absoluta, já que a conexão causal dos eventos intramundanos não é capaz de explicar por que existe o mundo e, menos ainda, um mundo como o nosso. Não se pode mais pensar a questão da ação humana a partir da natureza, mas a partir da vontade que, enquanto absoluta, transcende a ordenação causal dos eventos. Esta vontade livre é pensada como fundamento da existência de tudo, assim, toda a realidade criada é contingente: mesmo admitindo, que há uma ordem que tudo rege, esta ordem poderia ser outra ou mesmo todo o criado poderia não ser. Isto implica um questionamento radical da facticidade do mundo existente: sua existência perde a evidência, quando se tematiza seu fundamento livre. A origem do mundo é fruto de um ser que não faz parte do mundo, transcende, radicalmente, o próprio mundo e está, igualmente, presente em tudo, na essência de todas as coisas, que existem por participar em seu ser. Por transcender radicalmente a tudo, não está submetido, na criação do mundo, a nenhuma necessidade fora de si mesmo. A liberdade de Deus emerge como fundamento exclusivo da realidade não divina: tudo que é, enquanto tem ser, o tem de Deus. Assim, a ordem do mundo só pode ser pensada enquanto fundada na vontade de Deus. Aqui se abre o espaço para uma nova metafísica, uma metafísica da liberdade, já que a liberdade absoluta é a referência a partir de onde a totalidade é interpretada.

A metafísica da liberdade implica um novo horizonte para pensar a liberdade humana, pois a fundamentação da ordem do mundo na vontade de Deus é algo profundamente diferente da fundamentação da ordem do mundo num movimento cíclico. Para o pensamento clássico, o mundo possui seu fim e sua ordem imutável; cada fim no mundo se subordina a este fim do mundo enquanto tal. Na perspectiva do pensamento cristão, o mundo não tem, naturalmente, nem fim, nem

2 Cf.: Aristóteles, Et. Nic., III, 1-5. E. Tugendhat apresenta o que ele denomina o inventário da tradição filosófica desde Aristóteles: a tradição distinguiu entre uma vontade sensivel, imediata e uma vontade determinada pelo entendimento, pela razão, pela deliberação. $O$ critério de distinção é que para o primeiro tipo de vontade vale a escala agradável/desagradável, enquanto que, para o segundo, a escala bom/mau. Assim, pode-se responder de dois modos à pergunta: por que se fez algo? Porque me é agradável (neste caso, o ponto de referência último é a atual situação subjetiva) ou porque considero bom, ou seja, tenho razöes objetivas para agir assim. Terminologicamente se chamou à primeira forma de vontade de impulso, afeiçăo, apetite, desejo, enquanto a palavra vontade ficou reservada para a vontade que é determinada pela razão. Cf.: Tugendhat E., Selbstbewusstsein und Selbstbestimmung. Sprachaanlytische Interpretation, Frankfurt am Main, 1979, p. 150-151. Cf.: Tomás de Aquino, S. Th, 1 q. 80 a 2.

3 Cf.: Müller M., Existenzphilosophie im geistigen Leben der Gegenwart, terc. Ed., Heidelberg, 1964, p. 25 e ss.

4 Cf.: Krings H., Reale Freiheit. Praktische Freiheit. Transzendentale Freiheit, in: Simon J. (ed.), Freiheit. Theoretische und Praktische Aspekte des Problems, Freiburg/München, 1977, p. 96 e ss. 
ordem, já que todo fim e toda ordem do mundo se radica na liberdade de Deus, ou seja, toda ordem tem na vontade absoluta seu a prioni. ${ }^{5}$ Numa palavra, a liberdade absoluta é o a prion de qualquer ordem, o que significa dizer que a liberdade do ser humano não mais é pensada a partir da ordem cósmica, mas como relação a uma liberdade originária. ${ }^{6}$ É uma liberdade, que fundamenta a própria ordem, que estabelece fins e meios; é, portanto, a vontade que funda o próprio mundo e funda, conseqüentemente, as ações humanas. Dai por que as normas que regem a ação do ser humano no mundo não se legitimam mais na ordem eterna do próprio mundo,' numa lei natural eterna ou no eterno retorno do mesmo, mas na vontade incondicionada, em última instância, na liberdade de Deus. Ele é o princípio criador e, ao mesmo tempo, fim e princípio da plenitude. O ser humano é imagem de Deus enquanto é origem de suas obras, já que possui inteligência, livre arbítrio e poder de ação.' Enquanto tal, a criatura ser humano é chamada ao diálogo e à amizade com Deus e nisto consiste o fundamento ontológico da dignidade da singularidade e da personalidade do ser humano,' ser marcado tanto pela incompletude como por uma dinâmica interna para a própria plenificação no seio da ordenação criada por Deus e, portanto, racional e no retorno de toda a criação a Deus. ${ }^{\prime 0}$

Foi a partir deste duplo horizonte que a tradição articulou o conceito de liberdade como um conceito analógico, ou seja, ele é dito dos diferentes seres de acordo com sua forma própria de ser numa dupla significação. Em primeiro lugar, negativamente, liberdade significa uma relação de independência, ${ }^{\text {" um conceito }}$

- Todo ente criado é, a partir de sua própria natureza criada, isto é, já em si mesmo, ordenado para seu fim e traz, em si, os princípios para sua açăo própria em direçăo a seu fim. Mudança, devir, pluralidade, historicidade pertencem, constitutivamente, à forma positiva de ser da realidade criada na direção de um fim. Cf.: Heinzmann R., Der Mensch als Person. Zum Verständnis des Gewissens bei Thomas von Aquin, in: Gründel J. (ed.), Das Gewissen. Subjektive Willkür oder oberste Norm?, Duisseldor, 1990, p. 40.

- O que, no século passado, acentuou, em toda sua obra, Kierkegaard. O "si" (Selbst) é uma relação que se relaciona consigo mesma. Ele se assume a si mesmo frente ao Deus absoluto, que o interpela na fé e enquanto interpelado é consciente de si. O ser humano, enquanto relaçăo ao infinito, não é posto por si mesmo, mas por um outro e relacionando-se a si mesmo, relaciona-se com este outro. Enquanto ele se relaciona consigo mesmo, em sua autoconsciência, ele se põe a si mesmo, pois autoconsciência é, ao mesmo tempo, liberdade. Assim a síntese de finitude e infinitude no "si" se revela como tarefa. Cf.: Kierkegaard S., Krankheit zum Tode, Düsseldorf, 1957, p. 77 e ss. Cf a respeito: Pannenberg W., Anthropologie in theologischer Perspektive, Göttingen, 1983, p. 95.

Uma concepçăo necessitarista, que legitima uma visăo fatalista do universo como um todo e da açäo humana em particular.

- Cf.: Pesch O H., Thomas von Aquin. Grenze und Grösse mittelalterlicher Theologie, Mainz, 1988, p. 381 e ss. Para Tomás de Aquino, o ser humano, enquanto imagem de Deus, é senhor de sua ação, pois uma açăo, propriamente, humana (actus humanus) provém de uma deliberação da vontade, ou seja, nela inteligência e vontade participam. Tomás distingue tal ato humano de um ato, simplesmente, do homem (actus hominis), onde falta a participaçăo da inteligência e da vontade como é o caso nas criaturas não racionais. Cf: Tomás de Aquino, S. Th., I-II, 1 c.

Cf.: Tomás de Aquino, De ver. $5,3$.

Cf.: Baumann K1., Das Unbewusste in der Freiheit. Ethische Handlungstheonie im interdisziplinären Gespräch, Roma, 1996, p. 147.

1 Liberdade significa, assim, uma não dependência de algo e uma não determinidade em relaçăo a um fundamento de determinação, ou seja, libertas a coactione, tanto no sentido de independência frente a uma coação externa, quanto a uma fixaçăo interna numa determinação, como no caso dos animais que săo determinados a partir de dentro, isto é, por sua própria natureza, o que se mani- 
profundamente relativo, pois todo ser finito pertence a um mundo e está, necessariamente, em relação com outros seres neste mundo. Todo e qualquer ente finito pode estar, diretamente, livre em relação a este ou aquele ente, mas, precisamente, porque está ligado a outros entes. Assim, o ente que está livre da história, está ligado pela natureza e pelo cosmo. Um ente, neste sentido negativo, totalmente livre, sem relações, radicalmente isolado, não é mais um ente do mundo. A tradição, sempre, entendeu a negação, relativamente, uma vez que ela pressupõe o positivo. Portanto, uma liberdade negativa, pensada absolutamente, seria algo plenamente indeterminado, impensável.

Mas a tradição, sempre, também, conheceu um conceito positivo de liberdade: um ente é, positivamente, livre na medida em que ele se possui a si mesmo e tem, nesta relação consigo mesmo, o fundamento de seu ser e de seu agir. Foi nesta perspectiva que a tradição considerou, no desenvolvimento do real, a formação, cada vez mais acentuada, de centros subjetivos capazes de captar o que age sobre si e, de alguma forma, tomar posição sobre isto. Assim, por exemplo, em relação ao mundo anorgânico, a assimilação do seres vivos é um primeiro grau de autonomia, que atingirá um nível mais alto no movimento local e na sensação do animal que, já, age na natureza, embora permaneça, fundamentalmente, ligado a ela, uma vez que seus impulsos e instintos lhe são pré-dados pela própria natureza.

No ser humano, emerge a capacidade de controlar os impulsos em função de um fim mais alto, que é o que a tradição denominou livre arbítrio, o qual, para Hegel, ${ }^{12}$ constitui o degrau intermediário entre a vontade natural e a vontade, verdadeiramente, livre e que permanece no campo da heteronomia, uma vez que seu conteúdo é, simplesmente, encontrado: por esta razão a liberdade neste nivel é uma ilusão como Hegel concede ao determinismo. Só no nível da vontade livre para si há autoposse, o bastar-se pleno a si mesmo, autarquia, posse em si mesmo do fundamento e do fim. ${ }^{13}$ A liberdade humana é um misto de liberdade negativa e liberdade positiva. ${ }^{4}$ Sem dúvida, enquanto ser pessoal, ele é relação para consigo

festa no instinto, que leva cada animal, irrevogavelmente, para o seu caminho especifico. Em contraposiçăo a isto, o ser humano não é determinado instintivamente. Cf.: Lotz J. B., Person und Freiheit. Eine philosophische Untersuchung mit theologischen Ausblicken, Freiburg/Basel/Wien, 1979 , p. 11.

Cf.: Hegel G. W. F., Grundlinien der Philosophie des Rechtes, ed por Hoffmeister J, qua. Bd., Hamburg, 1955, § 15, p. 37-38.

is Para os gregos, uma caracteristica do divino, que, pensando a si mesmo, é fundamento e fim de si mesmo e com isto, plenamente, feliz. Cf.: Aristóteles, Met. 1074 b 34 e s. Hegel, por sua vez, em nenhum momento põe em questão o princípio de causalidade: sua critica ao arbitrio afirma expressamente que as pessoas que agem arbitrariamente são heterônomas, uma vez que livre só é aquele que segue a razão. Portanto, o conceito hegeliano de liberdade segue a concepção kantiana de que liberdade é independência do arbitrio. No entanto, Hegel năo acompanha Kant em seu conceito de liberdade transcendental, que pressupôe a teoria dos dois mundos (fenômeno e noumenon) e a negaçăo da validade do princípio de causalidade. Cf.: Hösle V., Hegelssystem. Der Idealismus der Subjektivität und das Problem der Intersubjektivität, v. II, Hamburg, 1988, p. 488.

G. Haeffner chama atenção para dois outros conceitos de liberdade muito conhecidos hoje. Em primeiro lugar, alguém é considerado livre quando pode, licitamente, fazer o que pretende, ou seja, quando tem o direito de agir deste modo e năo é limitado, no seu agir, por leis morais ou jurídicas. É neste sentido que se fala de liberdade de imprenșa, de religiảo, de associaçăo, etc. O segundo é o conceito de liberdade de açăo. Livre, neste contexto, é o que năo é impedido de realizar o que se 
mesmo, posse de si e posse do mundo, ${ }^{15}$ mas, igualmente, ser que vive numa situação que o determina, ${ }^{16}$ ser de um mundo já feito e sempre por fazer, dependente dos entes no seio dos quais se encontra e em relação aos quais vai desenvolver suas potencialidades, por fim, submetido às leis que regem o mundo no qual exerce seu domínio. Por isto, liberdade no sentido positivo, para o ser humano, é, em primeiro lugar, uma autodeterminação frente às determinações em que ele se encontra, ser senhor de si mesmo, o que só é possível enquanto transcendência sobre toda e qualquer facticidade. Esta unidade de liberdade negativa e positiva constitui, fundamentalmente, a liberdade humana em suas diferentes dimensões.

\section{A liberdade enquanto transcendência}

Qualquer forma de consciência pressupõe a capacidade de distinguir, de classificar; o que caracteriza o pensamento é a ordenação de tudo o que é experimentado sob uma rede categorial, isto é, a referência do que foi distinguido a horizontes de comunhão, o que significa dizer que cada impressão sensivel é subsumida a conceitos universais, " o que toma possível diferentes interpretaçōes da

propőe. Neste sentido se diz que um preso não tem liberdade. Cf.: Haeffner G., Philosophische Anthropologie, Stuttgart/Berlin/Köln, 1989, p. 130. A respeito da discussão atual sobre a problemática da liberdade cf.: Pothast U., Die Unzulänglichkeit der Freiheitsbeweise. Zu einigen Lehrstücken aus der neueren Geschichte von Philosophie und Recht, Frankfurt am Main, 1987.

15

Em graus diversos, porque, enquanto $o$ animal permanece fechado da esfera do vital e do sensivel sem poder superá-los na direção de outros valores, o específico do ser humano é, ao contrário, fazer surgir valores novos situando-se em diferentes niveis der ser : o nivel dos reflexos, das açōes instintivas, das açōes deliberadas, etc. Cf: Finance J. de, op. cit., p. 123 e ss.

Neste sentido, mundo significa, antes de mais nada, situação de ação, pois, em nossas açōes no mundo e em relaçăo ao mundo que nos marca, nos relacionamos, também, com nossas próprias possibilidades de existência. Nossas decisões sobre coisas são, também, decisōes sobre modos de agir, em última instância, decisões sobre nós mesmos e, em virtude de nossa finitude retroagem sobre nós. Cf.: Haeffner G., op. cit., p. 129 e ss. Para E. Tugendhat, Kant distinguiu, neste contexto, aspectos que ainda marcam nossa discussão, hoje, sobre a liberdade. Cf.: Tugendhat E., Ética $e$ Justificação, in: Veritas, v. 44, n. 1 (1999) 12: "O conceito de liberdade é ambiguo. Pode-se começar dizendo que uma pessoa é livre quando pode fazer o que quer; mas aqui se pode fazer a seguinte distinção: a açăo da pessoa é livre quando faz o que ela quer, mas é também livre o querer mesmo? ... não é suficiente saber se a açăo da pessoa é livre, livre porque baseada em sua vontade, mas se quer saber se a vontade mesma é livre, porque, se não é, não poderiamos dizer que a pessoa é responsável por sua ação, responsável no sentido de imputabilidade". p. 13: "Isso é o problema da liberdade da vontade que Kant já discute e que se segue discutindo hoje. Distinguem-se duas escolas: a compatibilista e a incompatibilista. A compatibilista diz que a causalidade e a liberdade não se excluem, que a liberdade é simplesmente uma maneira de comportamento causado. $O$ incompatibilismo diz que, enquanto uma ação é determinada por mim, não pode ser (ou nảo pode ser vista) como causada. Enquanto o incompatibilismo é defendido hoje, está sempre em perigo de ter de admitir que a liberdade é uma coisa de acaso ... se a ação é o produto de um acaso, năo poderíamos considerar a pessoa responsável".

Cf: Costa N. C. A. da, O conhecimento cientifico, Săo Paulo, 1997, p. 156: "Mas o aparelho sensorial não é o único fator de condicionamento do mundo que nos rodela. Outro é constituido pelo modo como pensamos. As categorias a que recorremos para descrever o universo também o condicionam. Através de conceitos que criamos, em boa medida motivados pelo próprio mundo, é que o conhecemos, o dominamos e fazemos previsões que se mostram essenciais para nossa subsistência". Contra o empirismo, Einstein insiste em que todos os conceitos, que emergem em nossos pensamentos e proferimentos lingüisticos, do ponto de vista lógico, são criaçōes livres do pensamento e 
mesma experiência. Somente pela mediação destes conceitos universais pode o ser humano reduzir a imensa complexidade do real por ele experimentado e, portanto, estruturar sua experiência de mundo. Eles cumprem, assim, função seletiva e, ao mesmo tempo, criam mundos espirituais que são, enquanto sistemas individuais e sociais de conceitos universais, inteiramente diferentes nas diferentes épocas e culturas. No entanto, apesar das diferenças, há pontos comuns e, sobretudo, a possibilidade de um debate sobre a unilateralidade de perspectivas específicas pressupöe que, em princípio, é possivel superar a perspectiva unilateral, ou seja, que há um sistema de validade ideal de conceitos universais como instância crítica dos sistemas reais. ${ }^{10}$

Na realidade, todos os conceitos são idealizações da realidade empírica e, por esta razão, emerge, inevitavelmente, a possibilidade da pergunta sobre a legitimidade destas idealizações. Ora, justamente, aqui, se situa a grande façanha do ser humano: ele levanta a questão da validade. Ele é, em princípio, capaz de se distanciar de suas próprias representações e de seus próprios desejos na medida em que pergunta se elas são verdadeiras e se eles são, moralmente, corretos. Numa palavra, o ser humano pode, em princípio, avaliar, julgar, transformar todos os estímulos que recebe do mundo em proposiçōes e afirmá-las ou negá-las. O ser humano pergunta e enquanto pergunta revela que, em princípio, pode distanciarse de tudo na medida em que pode submeter tudo à pergunta sobre sua validade. Como diz M. Scheler, o ser humano, comparado com o animal, é o ser que pode dizer não, 0 eterno protestante contra a simples facticidade, ${ }^{19}$ tanto a realidade externa como a realidade que ele próprio é, pois ele pode considerar, também, a si mesmo como um objeto. Numa palavra, as idéias do verdadeiro e do bom são as grandes descobertas do ser humano enquanto ser espiritual, e são inelimináveis, pois mesmo aquele que julga toda verdade uma ilusão tem que considerar verdadeira sua conviç̧ão.

$O$ verdadeiro e o bom abrem, para o ser humano, um espaço de liberdade: ele pode sempre se perguntar pelas razões teóricas e práticas de suas suposições e, com isto, se libertar das causas cegas que o impulsionam. Assim se revela que o ser humano está, sempre, para além de qualquer realidade dada, se abre a um horizonte mais vasto, ou seja, que ele não está ligado ao faticamente dado, mas transcende, em princípio, qualquer imediatidade. O ser humano, neste sentido, é o ser da absoluta distância: ele pode, em princípio, afastar tudo de si, mesmo tudo o

não podem ser, indutivamente, extraídos de nossas vivências sensiveis. 0 costume de vincular certos conceitos ou vinculaçōes de conceitos a certas vivências sensiveis torna dificil captar o abismo entre o mundo das vivências sensiveis e o mundo dos conceitos e das proposiçōes. Cf.: Einstein A., Bemwerkungen zu Bertrand Russels Erkenntnistheorie, in: Schilpp P. A. (ed.) The philosophy of Bertrand Russell, La Salle/III, qua.ed., 1971, p. 286 e s. Cf. th.: Quine W. V., Two dogmas of empiricism, in: From a Logical Point of View, seg. Ed., Cambridge/Mass., 1964, p. 44 e ss. Cf.: Hösle V., Moral und Politik. Grundlagen einer politischen Ethik für das 21. Jahrhundert, München, 1997 , p. 308-309.

10 Cf: Scheler M., Die Stellung des Menschen im Kosmos, dec. prim. ed., Bonn, 1988, p. 55. É isto o que constitui a abertura ao mundo, que é especifica do ser humano. Para K. Lorenz é no "jogo" que temos, diante de nós, o processo concreto de formação desta abertura ao mundo, que, em toda sua vida, vai constituir a caracteristica do comportamento, propriamente, humano. Cf.: Lorenz K., Die Rückseite des Spiegels Versuch einer Naturgeschichte des menschlichen Erkennens, 1973, p. 199201. 
que 0 aflige na medida que pode perguntar pelo sentido de tudo. Espiritualidade significa, assim, distanciamento, separação, liberdade, transcendência: posso afastar tudo de mim enquanto nomeio, capto, objetivo tudo, até a mim mesmo, ou seja, numa palavra, esta distância universal é, igualmente, transcendência, um estar para além de qualquer ente singular, inclusive para além de si mesmo enquanto realidade singular. ${ }^{20}$ A possibilidade da reflexão absoluta é idêntica ao que o ocidente denominou espiritualidade ${ }^{21}$ e constitui a liberdade originánia do ser humano enquanto ser espiritual que, com M. Müller, ${ }^{2}$ podemos chamar de liberdade transcendental por exprimir a transcendência, ${ }^{23}$ a indeterminação, a indiferença (liberdade de indiferença) ${ }^{24}$ específica do ser humano como ser-no-mundo frente às inúmeras possibilidades abertas que possibilita seu desligamento de tudo, de toda determinação e de toda impressão enquanto ele, na reflexão, pergunta pelo sentido de tudo e, assim, pode tomar posição em relação a tudo.

Para Hegel, ${ }^{25}$ isto constitui, precisamente, o primeiro momento da liberdade, que ele denomina "liberdade negativa" ou liberdade do entendimento, que é a

20 Cf.: Finance J. de, Essai sur l'agir humain, Roma, 1962, p. 199-200: "Parce que l'homme, consideré selon son Idéal et la forme objective de son activité, dépasse toute valeur particulière et donc sa propre valeur d'être particulier, il est toujours déjà au-delà de soj. Il n'est pas compris dans les bornes de sa nature finie..." Para Hegel, espirito é transcendência sem limites e transcendência sobre os limites que são negados de tal modo que o espírito se revela, em primeiro lugar, como negação. $\mathrm{O}$ que é negado pelo espírito é o limite, porque ele não reconhece nenhum limite como definitivo. $O$ limite, por sua vez, significa fim, negação. Na medida em que o espirito transcende o limite, ele nega o negativo do limite, ele é, em sua essência, negaçăo da negaçåo. Cf.: Müller M., Philosophische Anthropologie, op. cit., p. 90.

${ }^{21}$ Já, em Platăo, a conquista e o desenvolvimento da racionalidade constituem uma tarefa teórica e prática e implicam uma verdadeira reviravolta da existência humana, principiando com uma tomada de posição crítica das conviç̧ões vigentes no mundo do dia-a-dia, da dóxa. Cf.: Platão, Politeja, VII, 518 c 8,521 c 6 .

2 Cf.: Müller M., Freiheit, in: Erfahrung und Geschichte. Grundzüge einer Philosophie der Freiheit als transzendentale Erfahrung, Freiburg/München, 1971, p. 300. Pannenberg prefere chamar de liberdade formal, que se revela, na escolha, como o fenômeno originário e constitutivo do comportamento humano, enquanto humano, da transcendência sobre a facticidade. Cf.: Pannenberg W., Anthropologie, op. cit., p. 109.

23 Para Tomás de Aquino esta transcendência significa uma espécie de absolutidade formal do ser humano finito, que denomina uma certa participaçāo do ser humano no infinito, que, na medida em que o ser humano transcende qualquer ente singular, leva à plenitude a liberdade negativa. Cf: Tomás de Aquino, Caus. 16, 96 e ss; $S$. Th., Ia 12, 11, II, 87.

Cf.: Tomás de Aquíno, S. c. G. II 48; De Ver. 24,2 c. Lotz retoma a distinção, feita por Tomás de Aquino, a respeito de duas formas de liberdade relativas a pontos de partida diferentes (S Th 182,1 c; De ver. 22, 5 c; 2 Sent. 25, 1,4 ad 1; 2 c e 5 c; De malo 6, 1 ad 25) entre "coaçâo de fora" (libertas a coactione) e "fixação de dentro" (libertas a necessitate) com a finalidade de esclarecer o sentido da liberdade como autodeterminaçăo. No caso da coação exterior, o ser é violentado de tal maneira que não pode seguir seu próprio impulso assim que o uso da liberdade, só, é possivel quando tais injunções sẫo afastadas. No entanto, somente com isto ainda não se atingiu a liberdade como autodeterminação, como no caso do animal que, mesmo que seja libertado destas injunçōes externas, é fixado, internamente, por sua própria natureza, o que se manifesta na determinaçāo instintiva. Só o ser humano tem a capacidade de encontrar sue próprio caminho. Cf. Lotz J. B., op. cit., p. 110.

Isto é o que ele chama o elemento da indeterminidade pura ou da reflexão pura do eu em si mesmo, na qual qualquer limitaçăo, qualquer conteúdo é dissolvido. Trata-se, então, da infinitude sem limites da abstração absoluta ou da universalidade, o pensamento puro de si mesmo. Cf.: Hegel G. W. F., Grundlinien der Philosophie des Rechts, ed. por Hoffmeister J., qua. Bd. Hamburg, 1955, \& 5, p. 30. A respeito do fundamento lógico da concepção hegeliana de Liberdade, cf. : Müller M. L., A gênese lógica do conceito especulativo de liberdade, in Analytica, v. 1, n.1 (1993) 77-141. 
expressão da transcendência do ser humano, de sua capacidade de distanciamento de qualquer determinação, de sua capacidade de abstrair, de superar. A espiritualidade humana emerge aqui como o poder do negativo e o ser humano, enquanto espiritual como o ser da crítica, do questionamento, da transcendência sobre qualquer facticidade ${ }^{26} \mathrm{o}$ eu da indeterminação pura enquanto suspensão de todo conteúdo, de todo dado, universalidade abstrata pura, possibilidade pura. ${ }^{2}$ Os conteúdos são os impulsos, desejos e inclinaçöes através de que a vontade se acha determinada pela natureza e, por esta razão, possuem o caráter de algo natural, ou seja, algo dado, encontrado, distinto do eu ou da vontade. Em si eles derivam da própria razão, já que são suas possibilidades de determinação, mas a forma da imediatidade não é a forma da razão de tal modo que há, aqui, uma contraposição entre forma (infinitude) e conteúdo (finitude). Portanto, a vontade imediata é finita e sua finitude é o outro lado da "má infinitude" da indeterminação ou da abstração universal. ${ }^{2} \mathrm{O}$ eu é, apenas, formalmente infinito e, assim, a vontade tem a forma de uma reflexão fechada em si mesma, reflexão interna, pensar puro.

Donde vem ao ser humano esta capacidade permanente de transcendência? Para Hegel, a liberdade negativa não pode ser explicação de si mesma, pois ela nada mais é do que uma contradição, uma vez que se trata, aqui, do desejo de mostrar aos outros de que se é capaz de abstrair de tudo e de negar tudo, ou seja, de que não se é condicionado, numa palavra, com isto se mostra que se é condicionado pelo desejo de mostrar aos outros de que não se é condicionado. No entanto, enquanto o animal permanece na esfera da natureza, isto é, dos instintos e dos desejos, o ser humano pode optar por eles ou contra eles. $\mathrm{O}$ eu é a capacidade de transcender todo e qualquer conteúdo, mas, também, pode singularizar-se, individualizar-se na medida em que se decide, escolhe e, com isto, supera a má infinitude da universalidade abstrata e se finitiza, limita-se.

É isto que Hegel chama de "livre arbítrio", que é uma fase intermediária entre a vontade imediata, natural e vontade verdadeira, cuja substância, ou seja, a determinação essencial é a liberdade. ${ }^{20}$ No entanto, para Hegel, esta forma de liberdade é marcada por uma contradição decisiva: enquanto é universalidade abstrata, transcendência sobre qualquer conteúdo, a liberdade não tem realidade; quan-

26 Cf.: Bicca L., O conceito de liberdade em Hegel, in: Racionalidade e Subjetividade, São Paulo, 1997, p. 126: "Neste primeiro momento de vontade ela é, portanto, pura possibilidade, potência absoluta: o Eu transforma cada conteúdo em algo meramente possivel, em algo que é só pensamento, universalidade. A liberdade aqui é vazia, é puramente negativa, abstrata, já que qualquer conteúdo é rejeitado".

$\approx$ Cf.: Bicca L., A Revoluçấo Francesa na filosofia de Hegel, in: Racionalidade modema e subjetividade, op. cit., p. 90-91: "Sua lógica é a da redução do "em si" ao "para si", da dissolução prática de toda e qualquer objetividade na subjetividade consciente de si"... Oliveira M. A. de, Leitura hegeliana da revolução francesa, in: Ética e Sociabilidade, Săo Paulo, 1993, p. 229-230.

28 Cf: Bicca L., O conceito de liberdade em Hegel, op. cit., p. 133.

$\approx$ Cf.: Hegel G. W. F., Grundlinien, op. cit., \$ 4, p. 28-29. Cf.: Bicca L, Aspectos da critica hegeliana ao direito natural modemo, in: Racionalidade modema e subjetividade, op. cit., p. 109: "O livrearbitrio é aquela concepçăo espontânea de liberdade, típica das modernas sociedades civis, pela qual o sujeito se representa que "o ser livre é cada um fazer o que quiser"... o Eu ou a vontade humana se crê como o que é necessário e independente em face dos diversos conteúdos, supostos contingentes, em face dos possiveis objetos que se oferecem à sua escolha". 
do se realiza, mediante uma escolha, deixa de ser independente, pois depende de conteúdos contingentes, casuais, o que manifesta sua heteronomia, já que sua ação depende de seus impulsos e desejos e, portanto, de uma regra que não é, simplesmente, de sua razão. Por isto, tudo o que é, arbitrariamente, escolhido, pode ser, igualmente, abandonado e, neste sentido, o livre arbítrio é tão unilateral quanto a liberdade vazia enquanto transcendência. ${ }^{0}$ Desta forma, a liberdade, para Hegel, de nenhum modo pode esgotar-se na esfera da arbitrariedade da vontade, o ponto de vista do indivíduo isolado em si mesmo, da subjetividade atomizada, do ser-par-si absolutizado, onde o particular, enquanto particular é o essencial. A verdadeira liberdade só pode ocorrer quando o motivo último de nosso comportamento não é simplesmente reagir diante do que nos é dado, mas é agir de acordo com a razão," isto é, "uma pessoa é dita livre quando o fundamento determinante de suas decisões práticas não é algo extemo à razão, mas a própria razãon ${ }^{n}{ }^{n}$ portanto, só pode haver liberdade se é possível uma determinação autônoma e racional de fins últimos, ${ }^{30}$ racionalidade consciente, em que os impulsos e desejos "são incorporados num sistema de determinações da vontade fundado na razão", ${ }^{\text {, }}$ o que significa dizer que a liberdade pressupõe a autofundamentação última do pensamento.

O que caracteriza a fundamentação última é que ela chega a algo incondicionado, portanto, em certo sentido imediato, mas através da mediação argumentativa. Neste sentido se ultrapassa o nível das simples intuições que estão, em principio, sujeitas a objeções a respeito de sua validade. Por outro lado, a razão que chega ao incondicionado é uma razão finita, portanto, sujeita a falhas e, sempre, capaz de avançar na articulação de seu conhecimento. Trata-se, aqui, de uma reflexão que tematiza os pressupostos irrecusáveis inclusive da própria dúvida enquanto tal, ou seja, que estão presentes em qualquer tentativa de negá-las como condição transcendental do sentido desta negação. Neste sentido, trata-se de uma demonstração negativa, em que as sentenças de fundamentação última são provadas, indiretamente, através da autodissolução da posição contraposta, assim que uma sentença vale como fundamentada em última instância, quando não pode ser negada sem autocontradição pragmática e não pode ser demonstrada sem que sua validade seja pressuposta. Todo conhecimento que trabalha com um procedimento dedutivo não pode, por princípio, ter uma fundamentação última, o que manifesta o momento de verdade do falibilismo contemporâneo.

No Nerspectiva do livre arbitrio, o dever, o direito aparecem como algo exterior e negativo, como uma limitação e é, nesta ótica, que Hegel interpreta a definiçăo kantiana do direito. Cf.: Hegel G. W. F., Grundlinien, op. cit., \$29, p. 45.

Isto é, seguir uma regra a partir de razões que legitimam este comportamento. Cf.: Tugendhat B., op. cit., p. 267.

Cf.: Bicca L., op. cit., p. 121. p. 138: “...mas objetivar, produzir, criar o que ainda năo é, não está dado".

O que implica a unidade de pensamento e vontade. Cf.: Salgado J.C., op. cit., p. 239: "A vontade é um modo particular do pensar; o querer é exclusivamente humano porque é também representar pelo pensamento o que se quer, convertido ao mesmo tempo em objeto do pensar".

Cf.: Bicca L., op. cit., p. 138. 
O cerne do argumento de fundamentação última consiste em demonstrar que existe algo que é condição de possibilidade de todo e qualquer conhecimento com pretensão à verdade e isto, conseqüentemente, precede o conhecimento empírico. Por esta razão, não é possível admitir que exista algo no mundo que não seja determinado pelas categorias implícitas na fundamentação última, uma vez que elas explicitam, justamente, a estrutura racional de tudo. Numa palavra, a estrutura do pensamento não é algo, simplesmente, subjetivo, mas algo que subjaz a todo e qualquer ente e é isto que tem, na reflexão filosófica, prioridade lógica e ontológica. Isto significa dizer que, em última instância, no Absoluto, ser e pensar coincidem, isto é, a reflexão da reflexão é uma determinação ontológica, o que explica porque nós, na esfera do finito que é marcada pela diferença entre ser e pensar, podemos conhecer as estruturas do real, portanto, captar as essencialidades do mundo ideal, ${ }^{35}$ que constituem as essências do mundo real. É isto que explica, em primeiro lugar, a liberdade negativa: na medida em que espírito significa presença do incondicionado nenhum bem particular se impõe, obrigatoriamente, à sua adesão de tal maneira que o sujeito espiritual escapa às injunções de qualquer objeto, isto é, ele é capaz de uma permanente transcendência o que implica a superação do determinismo e nos permite compreender a liberdade negativa como um indeterminismo subjetivo. Precisamente porque o ser humano é presença do incondicionado, ele é capaz de transcender qualquer condicionado, qualquer valor particular de ser e, assim, está sempre para além de si mesmo. É a presença do incondicionado que lhe dá o poder de pôr em questão qualquer objeto, inclusive a si mesmo enquanto objeto de si mesmo.

3 A tradição metafisica do ocidente, sempre, apontou este conhecimento como condição de possibilidade da vontade livre. É o conhecimento que nos mostra possibilidades de nos decidir de acordo com nossa essência, portanto, o conhecimento nos oferece orientaçőes no nosso mundo e no todo da realidade. Como diz $\mathrm{E}$. Coreth, ele nos mostra valores ou não-valores, possibilidades autênticas ou não autênticas, verdadeiras ou falsas de nosso próprio ser. Nós mesmos, no entanto, temos que escolher, decidir. Somos livres em nossa auto-realizaçăo. Cf. Coreth E., Was ist der Mensch? Grundzüge einer philosophischer Anthropologie, Innsbruck/Wien/München, 1976, p. 100.

* Para Tomás de Aquino, só o bem pleno, Deus, pode saciar o apetite humano. Cf.: Tomás de Aquino, S. Th., I-II,5, 8 ad 3. Coreth, repensando a tradiçăo no horizonte da filosofia transcendental moderna articula, assim, o que ele denomina a "essência metafisica" da liberdade: o espírito humano capta qualquer objeto enquanto é, enquanto é ente, no horizonte do ser. Seu objeto formal, isto é, a perspectiva sob a qual ele conhece, é o ente enquanto tal. Seu objeto material é todo e qualquer ente, a totalidade da realidade. Entre o conhecimento e a vontade há uma correspondência, necessariamente, rigorosa, pois a vontade é a faculdade de apetite intelectual que é, essencialmente, correspondente ao conhecimento intelectual. Assim o objeto formal da vontade é o bem enquanto tal, a totalidade dos bens e valores. O objeto material é qualquer bem, qualquer valor. Portanto, seu horizonte é caracterizado por uma infinitude virtual, isto é, uma infinitude de uma antecipaçăo ainda vazia e aberta. Isto implica uma orientação dinâmico-final à plenitude infinita do ser e do valor. Assim, se na esfera do conhecimento, o entendimento transcende qualquer objeto finito na direção da verdade do ser mesmo na infinitude de sua plenitude e de sua riqueza, assim, também, a vontade, na dinâmica de seu movimento, ultrapassa qualquer bem finito singular e nunca pode neles encontrar sua plenitude. Só o bem supremo, o valor supremo plenificam seu horizonte. Nenhum bem finito pode, portanto, forçar nossa decisão. Nesta indeterminação está a essência da liberdade. Cf.: Coreth B., Was ist der Mensch?, op. cit., p. 108-110. 
O ser humano pergunta pela realidade em sua totalidade: se a liberdade transcendental, enquanto possibilidade de transcender tudo, ${ }^{n}$ enquanto o poder de pôr em questão qualquer objeto, valor ou quadro de valores, inclusive de pôr a si mesmo em questão, o que o constitui como ser espiritual, manifesta sua distância radical em relação a tudo, revela, também, seu vazio e, por esta razão, aponta para uma outra dimensão da liberdade. ${ }^{\Im}$ Enquanto liberdade transcendental, o ser humano se revela como o ser da distância e, com isto, da possibilidade universal: nada, em princípio, o prende. ${ }^{39}$ Mas, como ser do vazio, ${ }^{40}$ misto de ser e não-ser, ele se revela como aquele interpelado a ser, a passar da possibilidade à efetividade, a se construir, a construir seu próprio ser," a sair da distância da liberdade transcendental, portanto, a negar a negação de determinação e a se conquistar a si mesmo," a se dar a si mesmo, através de suas açőes, uma forma de ser através de que ele se produz ${ }^{\circ}$ de tal modo que o vazio se revela, agora, como o horizonte que possibilita ao ser humano assumir, enquanto liberdade produtiva, a gestação de seu ser" inclusive porque nele, em

37 De tal modo que tudo se toma objeto de uma afirmação ou negação. Portanto, a liberdade transcendental torna a objetivaçăo possivel. Cf: Müller M., Philosophische Anthropologie, Ed. por Vossenkuhl W., Freiburg/München, 1974, p. 117.

30

Precisamente porque esta postura é contraditória: a abstração de toda determinação já é uma determinação, contradição entre o que é afirmado e o que ela de fato é, o que leva o processo para frente.

Cf.: Finance J. de, op. cit., p. 200: "Objectivés, projetés devant nous comme un possible entre les possibles, le parti à prendre, l'action à poser aparaissent détachés, enveloppés d'une aura de doute. Notre champ pratique n'est plus rempli: il y a du vide, du flou, sur les bords... I va falloir choisir." Bicca L., op. cit., p. 126: "Neste primeiro momento da vontade ela é, portanto, pura possibilidade, potência absoluta: o Eu transforma cada conteúdo em algo meramente possivel, em algo que é só pensamento, universalidade".

Hegel chama a liberdade negativa de liberdade do entendimento, "pois o entendimento significa a faculdade das abstraçס̄es, das formas consideradas em oposiçāo a ou separadas do que pertence ao mundo sensivel"(Cf.: Bicca L., op. cit., p. 126).

$\mathrm{Na}$ idéia de liberdade encontra sua plenitude o momento do "para-si" na personalidade. Cf.: Pannenberg W., Anthropologie, op. cit., p. 233.

O ser humano é, enquanto espírito, diz Hegel, unidade de teoria e prática. Cf.: Salgado J. C., op. cit., p. 238: "Na acepção de Hegel, pensar é intelecto e vontade a um só tempo. Recupera-se a posiçâo originária de Platão (criticada em Kant) -, para quem a idéia é o dever-ser, o ser da realidade total, seja prática ou teórica, por ser o bern e a própria verdade". p. 239: "... o prático é o modo pelo qual o pensar se exterioriza na sua obra ... como prático o sujeito autodetermina pelo pensamento e, como teórico, o objeto se determina no pensamento". Para M. Müller, Hegel pensou a história, precisamente, enquanto passagem de uma liberdade transcendental, vazia para uma liberdade absoluta, realizada. Cf.: Müller M., Philosophische Anthropologie, op. cit., p. 131-132.

É neste sentido que Pannenberg vincula o conceito de pessoa com o conceito de liberdade no sentido de que liberdade significa mais do que a capacidade formal de distanciamento de tudo, que é dada com a abertura ao mundo, que caracteriza o ser humano. No sentido mais profundo, liberdade é possibilidade real de ser eu mesmo como expressão de minha identidade enquanto ser racional. Neste sentido, ser pessoa e liberdade se pertencem mutuamente na medida em que personalidade designa a presença do "si" no eu. Cf.: Pannenberg W. Anthropologie, op. cit., p. 233.

4 Na fantasia, o ser humano se experimenta tanto como criador, quanto como dependente. Daí a intima vinculação entre fantasia e liberdade. Cf.: Pannenberg W, Anthropologie, op. cit., p. 365 e ss. 
princípio, já estão incluídas todas as possibilidades, ${ }^{5}$ de se determinar a si mesmo, de atualizar o apenas possível, de ser o autor de seus próprios atos, de se dar a si mesmo as razões de seu agir e dos fins por ele buscados ${ }^{*}$ (libertas arbitrii, liberdade de decisão ou liberdade existencial). ${ }^{47}$

O ser humano se experimenta engajado num mundo que ele pode, em sua reflexão, pôr em questão, mas que ele sabe ser sua realidade: ele se conhece a si mesmo como inserido num todo natural e humano e de diferentes formas, condicionado por este todo, o que faz com que sua liberdade seja, essencialmente, limitada de tal modo que, em primeiro lugar, ela é fruto de uma conquista na medida em que o ser humano pode, a partir de seus condicionamentos, da situação que preexiste a ele, do mundo já decidido e feito, pleno de determinações, da esfera da singularidade, da individualidade, da particularidade, da materialidade, elevar-se à liberdade, ou seja, a agir de tal modo que não seja, simplesmente, determinado por sua essência, por seus impulsos e disposições, pelas gerações que o precederam, pela história mundial, pelos eventos sociais, o que significa dizer que não há liberdade sem processo de libertação,"

4 Cf.: Finance J. de, op. cit., p.208: “... la volonté, entant qu'elle s'ouvre à l'Absolu, enveloppe déjà, en quelque sorte, des déterminations particulières. Son indifférence à leur égard n'est pas de passivité et d' inertie mais de domination et dépassement: une indifférence active". Oliveira M. A. de, Direito e Sociedade, in: Ética, Justiça e Direito. Reflexōes sobre a reforma do judiciánio, org. por Pinheiro J. B./Sousa Júnior J. G. de/Amuda Sampaio P. de, Petrópolis 1996, p. 82: "A liberdade é, assim, também, o horizonte a partir de onde se pode pensar o mundo como o espaço onde o que está em jogo, em última instância é, justamente, a liberdade humana: a liberdade transcendental de si mesma aponta para o mundo como o espaço de sua efetivação".

46 Cf.: Finance J. de, op. cit., p. 209. Cf.: Ladrière J., Ética e pensamento científico. Abordagem filosófica da problemática bioética, São Paulo, s. d., p. 35: “... o ser do homem jamais lhe é dado, senão como apelo a si mesmo ... O ser humano é, ao mesmo tempo, um ser atualmente advindo e um ser ainda a vir, apenas prometido a si mesmo".

Cf.: Tomás de Aquino, S.c.G, II, 48. M. Müller considera esta experiência de que tenho que me assumir, num processo de gestaçăo de mim mesmo, mais originána de que a experiência da soberania espiritual e da distância. A liberdade, só, é experimentada aí, onde há necessidade: eu tenho que ser, eu devo ser apesar de este poder ser ameaçado e, em parte, vazio. Este vazio é, contudo, diferente do vazio da liberdade transcendental, pois o vazio é, aqui, experimentado como a necessidade, em que eståo minha missão e minha chance. A liberdade é experimentada na missăo com a chance de seu cumprimento e a possibilidade do fracasso. Cf.: Müller M., Philosophische Anthropologie, op. cit., p.134. Rombach H., Entscheidung, in: Handbuch philosophischer Grundbegniffe, ed., por Krings.H/Baumgartner H-M/Wild Ch., vol. II., München, 1973, p. 361-373. Tomás procura explicar a fonte do possivel fracasso pela distinção entre o bonum existens in se (I-II, 8, $1 \mathrm{c}$ ) e o bonum apprenhensum (I-II, 8, 1 c: "non requiritur quod sit bonum in rel veritate, sed quod apprenhendatur in ratione boni"). Assim, o objeto da vontade pode ser algo, verdadeiramente, bom, mas pode, também, ser algo, apenas aparentemente bom de tal modo que existe a possibilidade de que a pessoa humana se engane na consideração do verdadeiramente bom; pois, aqui, não se trata, simplesmente, daquela bondade que compete a cada ente enquanto é ente, uma vez que, nesta perspectiva, tudo pode ser objeto da vontade, já que tudo, enquanto é ente, é bom, mas da relação entre o objeto em questão e a pessoa. Numa palavra, para Tomás, o objeto da vontade não é, simplesmente, a coisa encontrada ou aquilo que se captou da coisa numa perspectiva, puramente, teórica, mas entra em consideração, aqui, a avaliação da coisa em relação à pessoa como um todo. Cf.: Baumann Kl., op. cit., p. 210 ess.

- Cf.: Boff L., O que é propriamente processo de libertação? Uma reflexăo sobre a estrutura, in: Teologia do cativeiro e da libertação, Lisboa, 1975, p. 87: "A condiçăo humana é assim que a liberdade não é nem totalmente independência nem totalmente autodeterminação. $O$ homem não é simplesmente livre das injunçōes de seu mundo (libertas a coactione), nem livre para auto-realizar- 
ou seja, sem a tarefa de o ser humano se conquistar a si mesmo como ser humano, de produzir, criativamente, uma configuração de si mesmo, de autodeterminar-se face às determinações prévias (libertas a coactione), ${ }^{\text {" }}$ numa palavra, 0 vazio da liberdade transcendental se manifesta como a necessidade de se construir a si mesmo, de se pôr na esfera da existência, da finitude, da partícularização, ou seja, de uma configuração específica do próprio ser e do ser do mundo, decidindo-se sobre si mesmo e sobre as possibilidades de sua própria existência, ${ }^{50}$ como chance e, portanto, tarefa histórica da construção ${ }^{51}$ do ser pessoal e social (liberdade transcendente) e, conseqüentemente, como possibilidade do fracasso; portanto, tem a ver com auto-identidade e auto-realização. Enquanto transcendência, o ser espiritual é possibilidade universal; mas, só somos enquanto determinados, enquanto a partir da possibilidade universal se apresentam a nós possibilidades determinadas, tarefas determinadas e é através delas que nos podemos fazer, concreta e efetivamente, livres nas situações históricas, através da produção de uma configuração sensata de nossas relações com a natureza e com os outros seres humanos.

É justamente a presença do incondicionado que torna a liberdade positiva possivel na medida em que se possibilita uma determinação racional e autônoma do ser humano: a ação humana tem um fundamento, isto é, um fundamento inteligível, já que ele tem acesso ao mundo ideal da validade pura e por isto pode

se plenamente (dominium super se ipsum). É senhor livre enquanto se liberta das conjunturas que o prendem, mas é cativo enquanto está sempre preso a uma situaçăo e mergulhado no mundo com o qual convive, depende de suas leis e a elas está sujeito", Cf.: Tomás de Aquino, S. Th., I, 83, 2 ad 3.

A tradição tomista distingue, aqui, entre a capacidade de agir assim ou assado, de escolher esta ou aquela possibilidade (iibertas specificationis, a captação de um fim determinado para a ação) e a capacidade de pôr um determinado ato ou não (libertas exercitii, a capacidade de realizar ou não uma ação na medida em que o ser humano pode refletir sobre o fim captado. Cf.: $S$. Th., I-II, 6, 2 c: "prout scilicet, apprenhenso fine, aliquis potest, deliberans de fine et de his quae sunt ad finem, moveri in finem vel non moveri"). Na liberdade de especificaçăo, trata-se da esfera de determinaçäo e, aqui, a inteligência pode mover a vontade. Bla apresenta o objeto à vontade (I-II, $9,1 \mathrm{c}$ ), aquilo que ela conheceu não só como ente e verdadeiro (razão teórica), mas que avaliou como bom para a pessoa (razão prática) e, portanto, como algo que se pode ambicionar. Ocorre, aqui, um movimento da vontade a partir do objeto. No que diz respeito ao exercicio, a inteligência não move a vontade, mas a vontade move a si mesma (I-II, 9,3). Portanto, na ação humana, inteligência e vontade estảo, intimamente, imbricados. Cf.: Finance J. de, op. cit. p. 210 e ss. Coreth E., op. cit. pg 103. Haeffner G., op. cit., p. 144 e ss. Baumann, op. cit., p. 207. Schockenhoff E., Wozu gut sein? Eine historischsystematische Studie zum Ursprung des moralischen Sollens. I. Thomas und Kant, in: Studia Moralia 33(11995)87-120. Isto significa dizer que, com a motivaçăo do ato de vontade, nẫo se suprime a liberdade, mas antes ela se torna possível, pois, só, posso decidir racionalmente, quando capto a racionalidade das diferentes possibilidades. Este conhecimento motiva, ou seja, fundamenta minha decisão, não a determina. Além disto, a pessoa pode experimentar, conscientemente, a vivência do conflito entre diferentes avaliaçōes de sua inteligência: uma segue a disposiçăo produzida pelas paixōes e a outra a disposição reflexiva da inteligência Cf. Coreth E., op. cit., p. 110. Baumann K1., op. cit., p. 221.

51 Cf.: Ladrière J., op. cit., p. 34-35: “... o ser humano ... se descobre a si mesmo, em sua ação, como um ser partilhado, como que cindido interiormente. Num certo sentido, ele já é o que podia ser, de certo modo sendo igual ao que é. Por outro lado, porém, em outro sentido, ele só existe à maneira do devir, ainda não é o que pode ser, aquilo que é chamado a ser, não sendo plenamente o que é. Portanto, tudo indica que existe, no ser humano, uma tensão interior fundamental entre o ser, tal como ele é dado no presente a si mesmo e o ser tal como ele aparece a si mesmo: como ser futuro". 
questionar toda validade empírica, fática. Sem dúvida esta liberdade é mediada por disposições de ordem biológica, cerebral, sociocultural, etc. ${ }^{52} \mathrm{O}$ fundamental, no entanto, é que, aqui, se trata de uma posição a partir da captação dos motivos, ou seja, da orientação na esfera da validade pura, ${ }^{53}$ o agir de acordo com a razão, numa palavra, liberdade, no sentido positivo, implica que o sujeito se determine a si mesmo, que seja ele mesmo o autor de seus atos (dominium super se ipsum), ${ }^{\text {st a }}$ causa de seu movimento e sua operação, que ele dê a si mesmo suas razões de agir e os fins que ele busca, ${ }^{55}$ seja ele mesmo o princípio de seu agir. ${ }^{56}$ Portanto,

\$2 Para Tomás de Aquino, na ação humana, está, necessariamente, presente o apetite sensível precedendo, acompanhando e seguindo $o$ apetite intelectual e isto independentemente do fato de $o$ homem ter consciência disto ou não. $\mathrm{A}$ forma de captar e avaliar o captado é o lugar de mediação para as influências internas e externas do ato humano. As influências externas, a partir do encontro com pessoas, eventos, coisas, são, internamente, captadas, avaliadas e, dinamicamente, respondidas com uma inclinação da açāo, primeiramente, de forma espontânea, no nível do sensível e, depois, com uma avaliação da inteligência. Ambas as fontes, a sensível e a inteligivel, constituem, para Tomás, a raiz, a condiçăo de possibilidade da liberdade humana. Cf.: Baumann Kl., op. cit., p. 205 e ss.

$\mathrm{O}$ acesso à esfera da validade pura nos torna capazes de conhecer uma hierarquia de bens e de fins, o que é indispensável para a açäo livre no sentido da liberdade positiva. Trata-se de um elemento necessário, embora não suficiente, para a compreensão de nossa liberdade. É por esta razão que, segundo M.Müller, nossa decisāo concreta, se radica em duas raizes, ou seja, em nossa perspectiva, é síntese de opostos: no conhecimento da ordem essencial universal e no saber da decisăo momentânea. A ordem universal nos diz o que não devemos fazer, o que a prion está excluído $\mathrm{e}$ sem este saber corremos, sempre, o perigo de cair no caos subjetivo, pois não temos critério para distinguir que é interpelação do ser e o que é voz de nossos próprios desejos. No entanto nåo basta, a liberdade, só, é verdadeira, quando é liberdade criativa na situação, efetivação da ordem essencial dentro das exigências de um momento histórico, o que implica a necessidade de sua traduçăo no momento especifico. Cf.: Müller M., Existenzphilosophie, op. cit., p. 86-87.

Cf.: Tomás de Aquino, S. c. G., II, 48. E. Tugendhat entende liberdade como a capacidade de comportar-se deliberadamente, o que nos distingue de um puro produto de uma causalidade cega. Cf:: Tugendhat E., Ética e Justificaçăo, in: Veritas, v. 44, n. 1(1999)26: "No caso fictício deste fatalismo real, nos converteriamos em puros espectadores do que ocorre em nós, de maneira algo semelhante à pessoa compulsiva que se vê impotente diante de uma parte de suas motivaçöes; ali como aqui, a pessoa se converte em puro espectador - aqui completo, ali parcial - diante de um jogo puramente causal de forças que a arrastam sem nenhuma possibilidade de ação própria. Isso é talvez o pesadelo errôneo do filósofo que crê que para todo ser causado a liberdade seria impossivel. Poder-se-ia dizer, de um modo quase paradoxal, que a liberdade mesma é causada, é um fenômeno causal, mas com isso não perde suas características. 0 essencial para mim consiste em darmo-nos conta de que o oposto de ser livre não é o ser necessitado (determinado), mas o ser compulsivo".

Para Tomás de Aquino, o fim, determinado pela vontade que deliberou, especifica, enquanto bem ambicionado, a forma e o caráter ético da ação humana. O fim é a primeira causa, que movimenta a vontade para uma ação. Cf.: Tomás de Aquino, S. Th., I-II, 1, 3 c e I-II, 1, 1 c e 1, 3 ad 2. Numa argumentação análoga à que é apresentada na esfera da razäo teórica, Tomás afirma que toda ação humana orientada para um fim, necessariamente (ou seja para evitar o regressus ad infinitum), exige um fim último. Cf.: I-II, 1, 4 c. Finance J. de, op. cit., p. 209. Para M. Müller, a escolha da ação é, sempre, motivada, ou seja, determinada através de uma escolha prévia, a opção fundamental e, neste sentido, a maior parte dos nossos atos não é livre, isto é, indeterminada e quando nossos atos aparecem indeterminados, portanto, como açöes insensatas do arbitrio, na realidade, determinadas pela perplexidade, pelo desespero e pela casualidade, com muita razão, podemos dizer que nossas açöes concretas, de certo modo, são determinadas. Cf.: Müller M., Philosophische Anthropologie, op. cit., p. 170.

* É neste sentido que M. Müller diz ser a liberdade do ser humano o princípio primeiro incondicionado de seu agir, ou seja, liberdade de espontaneidade e, enquanto tal, imagem do Absoluto. Cf.: 
liberdade, em sentido pleno, é autodeterminação: a ação livre é aquela em que o ser humano se determina a si mesmo ao invés de ser determinado por outros poderes, unidade, portanto, de indeterminação e determinação, ${ }^{57}$ numa palavra, ação em que o ser humano não é, simplesmente, o produto de causas fora dele mesmo, mas determinado pelo que é racional (liberdade de espontaneidade). Pode-se dizer que a auto-determinação pressupõe que a totalidade do ser e do comportamento humano não estejam, previamente, fixados, portanto, que a nãodeterminidade é condição de possibilidade da liberdade. No entanto, ela não constitui a essência da liberdade, mas apenas sua pré-condição, ${ }^{\circledR 0}$ o que já se mostra no próprio sistema instintivo humano, que é, fracamente, desenvolvido, o que tem como conseqüência que o ser humano não é, de antemão, fixado por seus instintos, portanto, que a determinação biológica do comportamento humano é aberta a uma possivel autodeterminação. ${ }^{50}$ Assim, o que caracteriza a ação livre é que, por sua mediação, o sujeito espiritual configura seu próprio futuro ${ }^{\infty 0}$ de tal modo que sua indeterminação é a abertura do espaço para sua autodeterminação.

Müller M., Freiheit, op. cit., p. 302. Sobre a relação dialética entre determinação $\mathrm{e}$ indeterminação, necessidade e liberdade, cf.: Haeffner G., op. cit., p. 144 e ss. E. Tugendhat, por sua vez, na otica da filosofia analítica, defende a tese do compatibilismo entre determinação e liberdade. Cf.: Tugendhat E., Ética e Justificação, in: Veritas, v. 44, n. 1(1999)24: "A imputabilidade é a caracteristica dos que podem deliberar e a compulsividade é o caso em que esta capacidade é inibida. A liberdade em que consiste a imputabilidade não tem como contrário o comportamento determinado, causado, mas um comportamento causal particular ao qual a deliberação não tem acesso. Mas a deliberação é igualmente um comportamento causalmente determinado; depende de motivaçōes causadas... Se a pessoa não continuasse a deliberar, porque sabe que objetivamente está predeterminada se vai deliberar ou não, ocorre um contrasenso. A atitude que ele então adotaria chama-se fatalismo. Fatalismo é a opinião que para o que se faz não faz uma diferença se se delibera ou năo. Mas é óbvio que faz uma diferença e que o fatalismo é falso; se eu venho a deliberar porque sou fatalista, isso é uma maneira livre de mudar as coisas e é uma maneira autodestrutiva. Da doutrina de que tudo está determinado não segue o fatalismo (quer dizer a renúncia à própria liberdade)".

Cf.: Hegel G. W. F., Grundlinien, op. cit., $\$ \$ 6$ e 7, p. 37-41.

so Cf.: Lotz J. B., op. cit., p. 109. Neste sentido, a ausência de causalidade ainda não significa, propriamente, liberdade. K. Larenz afirma que determinismo e indeterminismo coincidem enquanto necessidade exterior e contingência. Ambos dizem, no fundo, o mesmo: a casualidade da vontade. Cf.: Larenz K., Hegels Zurechnungslehre und der Begriff der objektiven Zurechnung, Leipzig, 1927, p. 47.

5 A respeito de uma consideração desta problemática na antropologia moderna cf: Müller M., Philosophische Anthropologie, op. cit., p. 70 e ss. Tugendhat B., Ética e Justificação, in: Veritas, v. 44, n. 1(1999)25: "Uma motivação que eu tenho vai comportar-se de outra maneira, se a tenho sob controle de minha deliberação: ela, então năo age cegamente, simplesmente por meio do mecanismo de mais ou menos prazer ou dor, senão é vista como mais ou menos boa; eu posso pôt então a motivação ou o desejo numa relação evalorativa às outras motivaçōes e desejos. 0 desejo, entåo, năo me determina simplesmente, não me domina, mas eu domino o desejo".

œ Para Tomás de Aquino, enquanto 0 animal, não havendo algum empecilho, traduz os componentes dinâmicos, automaticamente, num movimento exterior, no ser humano, ocorre, necessariamente, a participaçăo da inteligência e da vontade: o fim e o caminho para o fim são, de alguma forma pensados, a ação é escolhída, pelo menos com uma aprovação da vontade aos impulsos sensiveis. Cf.: Baumann $\mathrm{Kl}$, op. cit., p. 181. Isto significa dizer que, para Tomás, a ação humana, só, pode ser entendida através da complementaridade entre apetite sensivel e apetite intelectual. Cf. Baumann Kl. op. cit., p. 182 e ss. 
Nisto se revela, mais uma vez, o paradoxo do ser humano de ser tanto natural como espiritual. Enquanto ser de natureza, ele se sabe, sempre, inserido no todo da natureza, do mundo, da história, da comunidade com outros seres humanos e determinado por este todo. Inserção significa, aqui, determinidade, condicionalidade, dependência e, nesta perspectiva, o ser humano é, amplamente, um ser não livre. Enquanto ser espiritual, contudo, ele transcende tudo pela distância absoluta, se revela como o ser da possibilidade universal e, enquanto tal, ainda nada determinadamente. É enquanto tarefa no mundo que a liberdade emerge, propriamente, como liberdade humana, enquanto liberdade das decisöes, que ocorrem enquanto escolha de um ato determinado no espaço de muitos outros possíveis no seio do mundo, o que revela que o ser humano é, ao mesmo tempo, condicionado e incondicionado, ente contingente e não contingente.

É precisamente o sentido positivo da liberdade que permite compreender que o puro arbítrio não é, propriamente, liberdade, pois isto significa submeterse aos caprichos do acaso. Neste sentido, o libertinismo pretende que a ação humana parta da distância absoluta da liberdade transcendental sem nenhum fundamento, portanto, sem necessidade interna. Ora, é afirmação de um sentido racionalmente captado que garante a autonomia do espírito frente às forças cegas do arbítrio. Por esta razão, a liberdade implica, sempre, motivação, ou seja, a deliberação racional ${ }^{61}$ a respeito dos motivos a favor ou contra a escolha de um determinado valor, numa palavra, a ação livre é orientada e determinada por razões, cuja influência não exclui a autodeterminação, mas antes a prepara. A ação escolhida, só é livre quando ela é portadora de um sentido, isto é, quando é dotada de um valor que temos razöes para preferir a outros valores; numa palavra, a escolha livre é sempre fundada, implica uma referência, embora esta referência não possa motivar, totalmente, a escolha, uma vez que, em princípio, pode haver várias possibilidades de efetivá-la de tal modo que a decisão, em certo sentido, é sempre um salto, já que não podemos ter a certeza plena de qual é o melhor caminho.

No nosso caso específico, é valioso aquilo que, em primeiro lugar, se revela como realizador de nossa essência: quando agimos, queremos realizar-nos a nós

61 Uma deliberação sobre o que queremos e nela, em última instância, sobre quem queremos ser. Cf.: Tugendhat E., op. cit., p. 219. Cf.: Tomás de Aquino, S. Th., I-II, 1, 1 ad 3. Para J. B. Lotz, é importante distinguir entre 0 objeto material e $o$ objeto formal da vontade, quando consideramos a liberdade enquanto escolha. $\mathrm{O}$ objeto material é aquilo sobre que se faz a escolha, os entes, que atraem nosso apetite ou nossa vontade de acordo com sua bondade. Cada ente participa no ser de acordo com sua essência, consequientemente, seu grau de bondade é correspondente à sua essência. Daí porque a deliberação tem, sempre, que considerar os motivos a favor e os motivos contra para a escolha de um bem específico. O objeto formal é, sempre o mesmo, a bondade enquanto tal, o incondicionado, o ser em si mesmo, o que torna qualquer escolha possivel, isto é, precisamente pela infinitude do objeto formal, nossa liberdade é aberta frente a todos os bens finitos e nenhum escapa à sua escolha e, ao mesmo tempo, nossa vontade é livre em relação a todos eles, uma vez que nenhum deles consegue saciar a amplidão de seu horizonte. Assim, o ser humano é tanto mais livre em relação ao finito, quanto mais ele se radica no infinito, ou seja, a presença do infinito nele é condiçăo de possibilidade de sua liberdade. O Absoluto é a raiz da liberdade. Cf: Lotz J. B., op. cit., p. $124-128$. 
mesmos, realizar nossa essência. ${ }^{\text {E }}$ É neste sentido que, para M. Müller, ${ }^{\text {"n }}$ a escolha de nossas ações e dos entes aos quais elas se relacionam é precedida por uma

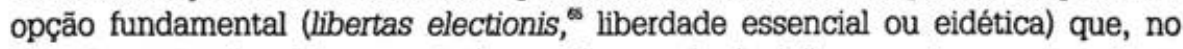
sentido estrito da palavra, poderíamos chamar de decisão, ou seja, uma escolha a respeito de nosso próprio projeto de vida, da configuração de nosso ser. É somente a partir desta decisão fundamental que algo pode revelar-se como fundamento de determinação ou motivo de nossas ações.

Quando se fala em essência, fala-se em sentido fundamental, em posição fundamental do ser humano no todo de tal maneira que afirmação de uma essência significa, igualmente, afirmação do mundo, da totalidade na qual esta essência, este sentido fundamental tem significação e validade de tal modo a decisão por um sentido fundamental da própria existência, a decisão por seu próprio ser implica, sempre, uma decisăo pelo mundo, por uma configuração específica da ordem do todo do ser (liberdade ontológica). ${ }^{*}$ Todos os nossos motivos se situam no horizonte da liberdade essencial e da liberdade ontológica: nesta liberdade de decisão se situa, propriamente, a liberdade pessoal" em que o ser humano concretiza sua transcendência sobre o mundo na direção da configuração ativa do mundo através da afirmação de uma essência e de uma totalidade, o que faz com que sua liberdade nada tenha a ver com o arbítrio caótico e infundado. Assim, podemos dizer que o ser humano, enquanto ser espiritual, ser da transcendência e do engajamento, não simplesmente tem liberdade, mas é, no mais profundo de si mesmo, liberdade.

(*) Como o ser humano é, diz Lotz, fundamentalmente, abertura ao ser enquanto tal e, só, se entende através desta relação toda decisão frente ao ser é, também, uma decisão sobre o ser humano e vice-versa. $\mathrm{B}$ é, precisamente, a partir daqui que se entende a liberdade enquanto autodeterminação, pois a presença do ser enquanto tal torna a distância de si mesmo e a disposição sobre si mesmo possíveis e como, também, a liberdade frente a todos os outros entes. Cf.: Lotz J. B., op. cit., p. 136. Para Oeing-Hanhoff, a consideração necessária do fim da vontade, em Tomás de Aquino, implica que a liberdade, sem dúvida, seja auto-realização num duplo sentido, isto é, no sentido de realizar-se a partir de si e através de si pela mediação de uma determinaçâo própria $e$, igualmente, no sentido da realização da própria essência na direção de seu ser pleno. Cf:: Oeing-Hanhoff L., Zur thomistischen Freiheitslehre, in: Scholastik 31(1956)177. Cf.: Müller M., Philosophische Anthropologie, op. cit., p. 143.

Cf.: Tomás de Aquino, 2 Sent., 15, 1.30.

* Cf.: Müller M., Freiheit, op. cit., p. 303-304. Para Lotz, por trás de cada decisão, há não só uma decisăo sobre o próprio eu e a totalidade histórica na qual ele está inserido, mas em relaçăo ao ser enquanto tal. A liberdade de decisão implica, assim, o ser mesmo juntamente com a dimensão mais profunda do ser humano, uma vez que o profundo do ser humano é abertura ao ser enquanto tal, ou seja, à esfera do incondiçionado, que atematicamente, está, sempre, co-presente em nossas decisōes. Cf.: Lotz J. B., op. cit., p. 130-133.

Que é um permanente processo de libertação, uma vez que o pessoal está inserido no não-pessoal e emerge, sucessivamente, a partir daqui proporção de seu amadurecimento. Cf.: Lotz J. B., op. cit., p. 113.

Lotz denomina a liberdade do ser humano, frente a todo finito, de liberdade derivada, que se radica na liberdade originária, que constitui a própria essência do ser humano, isto é, a presença do $\mathrm{Ab}$ soluto. Liberdade frente aos entes, só, é possivel pela relação ao ser através de que a vontade é liberada da violaçăo pelos entes. Cf.: Lotz J. B., op. cit., p. 138. 
A liberdade transcendente, a liberdade da ação, é passagem da distância absoluta para a configuração de nossas vidas históricas, que se efetivam enquanto construção das relações que nos caracterizam: relação com a natureza e relações com os outros humanos. O processo reflexivo mostra o ser humano como presença do incondicionado, que não pode ser negado a nível proposicional sem ser pressuposto a nível pragmático, portanto, como princípio que se fundamenta a si mesmo, então, princípio de todo pensar, de todo agir, de todo ser, numa palavra, princípio de toda a esfera do real, do mundo natural e do espiritual, do mundo subjetivo e do mundo intersubjetivo. Sendo presença do incondicionado, o ser humano é, fundamentalmente, aberto a toda e qualquer realidade, relação a tudo, comunhão ontológica com o todo da realidade, explicitação e articulação do sentido de tudo e, portanto, capacidade de captar o valor intrínseco de tudo, conseqüentemente, possibilidade de um relacionamento com tudo de acordo com 0 valor intrínseco de cada realidade. ${ }^{60}$ Mas, antes de mais nada, enquanto presença autopresente do incondicionado, ele pode comunicar-se com o outro sujeito que, enquanto tal, é também presença do incondicionado e, assim, aberto ao sentido de si mesmo, do outro de si e do mundo.

A primeira conseqüência disto é que a liberdade humana só é liberdade efetiva enquanto liberdade no mundo da natureza e da sociabilidade, ou seja, quando ela se faz o fundamento que alicerça a relação com a natureza e a vida comum dos sujeitos entre si., quando ela se faz o princípio e o fim de todas as configurações que mediatizam o ser comum dos sujeitos ${ }^{x}$ e de sua relação com a natureza. Então, se a liberdade, no primeiro momento, é transcendência, autonomia do eu sobre toda facticidade, a liberdade do vazio e da destruição, pois frente a ela toda positividade se dissolve; se, num segundo momento, ela é decisão, tomada de posição frente a uma multiplicidade de possibilidades, ela só se plenifica na medida em que se exterioriza, se faz mundo, se autoconfigura como ser efetivo na natureza e na sociedade, enquanto expressão do incondicionado que a interpela, na exterioridade, na esfera do mundo objetivo, isto é, na medida em que se faz o evento da produção comum de configurações do ser humano que medeiam seu ser como ser da autodeterminação, portanto, enquanto sintese de subjetividade e intersubjetividade, de interioridade e exterioridade. ${ }^{n}$ Assim, por exemplo, no co-

6 O formalismo ético, de tipo kantiano, é capaz de demonstrar a validade absoluta das sentenças éticas na medida em que mostra que tal validade não tem fundamento empírico, ou seja, nāo depende de localizaçăo, nem da cultura, etc. No entanto, é incapaz de dirimir os conflitos humanos concretos, nas situaçōes históricas especificas, onde ocorre a colisāo de normas e é necessário um princípio que indique a prioridade. Tal princípio, só, pode ser o valor intrínseco de cada ente, o que nos leva a uma ética material de valores, que nos toma capazes de estabelecer uma hierarquia de bens e valores. Cf.: Hösle V., Moral und Politik, op. cit., p. 154 e ss.

Hegel fala da conciliação entre as vontades particulares e a vontade substancial, o que ocorre, em última instância no Estado, onde se efetiva a correspondência de direitos e deveres. Cf: Hegel G. W. F., Grundlinien, op. cit., § 155, p. 148.

n Cf.: Oliveira M. A. de, Direito e Sociedade, op. cit., p. 83: "A liberdade humana, enquanto liberdade finita, é um processo: parte da liberdade transcendental para uma opção fundamental sobre a configuraçăo de si mesma e sobre seu mundo e daí para as opções individuais do dia-a-dia em que 0 ser humano pode ir construindo-se através da construção de obras que medeiam seu ser". 
nhecimento, em seus diversos niveis, o exterior a mim se faz presente em minha intimidade, se torna minha essência, e deste modo se efetiva a sintese entre interioridade e exterioridade. ${ }^{n}$

M. Müller ${ }^{3}$ distingue, neste contexto, entre liberdade da natureza, que existe aí onde a natureza é, em parte, indeterminada, isto é, tanto no microcosmo como na esfera do orgânico, e a liberdade do ser humano, onde emergem propriamente a necessidade histórica e a liberdade histónica. Aqui, a liberdade está sob a necessidade de produzir uma configuração, que ainda não está dada, a priori, em todas as partes. Neste sentido, o ser humano é ser do futuro, porque liberdade interpelada a produzir uma configuração futura de nós mesmos e do mundo comum.

Numa palavra, liberdade efetiva é liberdade enquanto construção intersubjetiva de relações, a construção do ser pessoal como ser-com-a alteridade, decisão a respeito da configuração específica deste ser-com. Assim, o que está em jogo no processo de libertação e que torna possivel a constituição dos sujeitos enquanto sujeitos, é este processo de construção de comunhões, como espaços de efetivação da liberdade na contingência dos eventos, das situações e das coisas, o que só pode emergir quando ela se faz produtiva: a busca de uma configuração num momento histórico determinado e, por isto, único. Por esta razão, interioridade pura e exterioridade pura não podem constituir a liberdade: ela se efetiva enquanto sintese de opostos, do interior e do exterior. A liberdade, então, só é livre enquanto história da luta pela produção das obras que constituem formas da efetividade de nossa vidas. Por esta razão, uma liberdade somente interior não é, propriamente, liberdade, mas ela é efetiva quando é unidade de ambos os aspectos, da universalidade e da particularidade, do pensamento e da ação, da transcendência e do engajamento, da possibilidade e da realidade, da forma e do conteúdo que são momentos de uma mesma totalidade.

A ação no mundo medeia transcendência e engajamento: a liberdade só é real pela mediação das obras no mundo, portanto, enquanto processo de sua efetivação nas contingências da histónia através de suas produções. Nesta perspectiva, o processo de libertação emerge como um processo circular, sempre recomeçado, entre o horizonte de infinitude da liberdade enquanto transcendência e a finitude das realizações contingentes da liberdade enquanto engajamento, que é produção de um mundo enquanto conjunto de obras que gestam o espaço da liberdade efetiva.

A obra é a síntese que constitui a liberdade enquanto liberdade: por um lado, pertence ao mundo das objetividades exteriores aos sujeitos, mas, por outro lado, é sua produção comum, encamação, exteriorização de sua autodeterminação interior.

$n$ A respeito desta problemática no pensamento de Hegel, cf: Oliveira M. A. de, Hegel: Normatividade e Eticidade, in: Ética e Sociabilidade, São Paulo, 1993, p. 212 e ss. p. 219-220: "A liberdade só é efetiva enquanto "mundo livre", existência exterior, mundo produzido pelo espirito como segunda natureza. Este mundo é novo à medida que é produzido resulta da vontade livre dos homens. Em contraposiçăo, portanto, ao conceito moderno da clência do etos, elaborado pela filosofia transcendental (Kant, Fichte) em que a ação ética é reduzida à esfera da açăo interior, Hegel mobiliza seu pensamento para situar a açăo na "substância" das relações éticas e, assim, superar a contraposiçăo entre o mundo da experiência e o mundo da razão".

Cf.: Müller M., Philosophische Anthropologie, op. cit., p. 118-120. 
Sem a sintese de seus dois momentos constitutivos liberdade não passa de possibilidade. Mas, por outro lado, como todas as sinteses são contingentes e finitas, a história é, por essência, um processo aberto, já que nenhum mundo histórico pode levantar a pretensão de efetivação plena do horizonte de absolutidade, que marca a existência humana: toda realização histórica da liberdade implica a possibilidade de outras realizações na medida em que todas elas são marcadas pela contradição entre a infinitude do horizonte e a finitude da efetivação. ${ }^{*}$ Daí porque pertence à estrutura da liberdade a necessidade permanente da escolha de novas configurações de nosso ser e do mundo que nos medeia, pois só assim podemos escapar ao vazio da universalidade abstrata de nossa transcendência sobre todos os mundos.

A primeira destas configurações é nossa relação com a natureza: se o incondicionado se revela como princípio de toda a esfera do real, então ser humano e natureza não podem ser pensados como esferas totalmente separadas, mas como essencialmente relacionados entre si, ou seja, marcados por uma comunhão ontológica fundamental. $O$ ser espiritual transcende a natureza ${ }^{\pi}$ na medida em que é presença auto-presente do incondicionado e nisto consiste seu privilégio: ser capaz de conhecer a alteridade e, portanto, o valor que cada ente tem enquanto presença do incondicionado de tal modo que seu relacionamento com a natureza precisa ser pautado pela captação de seu sentido, ou seja, pelo respeito por sua alteridade, pelo cuidado por sua conservação e integridade. ${ }^{7}$

Se a liberdade é um processo que se efetiva enquanto síntese de opostos, ela encontra seu grau supremo de efetivaçäo na conquista da subjetividade dos sujeitos $^{n}$ na esfera da cultura, ${ }^{7}$ isto é, do mundo das relações sociopolíticas construído pelo ser humano, o que só pode acontecer na medida em que os sujeitos efetivam, em suas vidas, o universal, que significa, superam qualquer perspectiva de coisificação e se reconhecem mutuamente como seres, fundamentalmente

74 Para Tomás de Aquino, o primeiro principio da vontade tem que ser, a partir da própria essência da vontade, um fim último. O ser humano busca este fim último em todo querer e em toda ação, já que, em cada querer particular, ele busca um bem particular na direção de sua própria plenitude e esta é, na ordem da causalidade dos fins, a que movimenta todo querer particular, mesmo que o agente não tenha consciência deste fim último. Cf.: Tomás de Aquino, S. Th., I-II, 1, 5; I-II, 1, 6. Baumann Kl. Op. cit., p. 151. Tomás admite, que, facticamente, há uma diversidade de interpretaçōes deste fim último da vida humana (I-II, 1, 7 c), no entanto, objetivamente, o fim último de todo ser criado, portanto, também, do ser humano, só, pode ser Deus. A forma como o ser humano atinge o fim último (conhecer a Deus e amar Deus, o que se plenifica na visão beatifica: $1-I,, 3,8 \mathrm{c}$ ) é o que distingue, essencialmente, o ser humano, enquanto ser racional, de todas as demais criaturas.

T É neste sentido que Hegel dizia que o universal está na natureza, apenas, em si e, so, no homem em si e para si, pois só o homem é capaz de se reconhecer como um individuo que é particular e universal, um representante do gênero humano, ou seja, ele é ao mesmo tempo, idêntico e diferente de todos os outros. Cf.: Hegel G. W. F., Enzyklopädie der philosophischen Wissenschaften im Grundinsse (1830), ed. por Nicolin F./Pöggeler O, Hamburg 1959, § 24, Zusatz, p. 58. Cf.: Boff L., Saber cuidar. Ética do humano - compaixão pela terra, Petrópolis, 1999, p. 133 e ss.

$\pi$ Hegel explicitou este processo através da parábola do senhor e do escravo. Cf.: Salgado J. C., op. cit., p. 255: "O significado mais profundo da dialética do senhor e do escravo é mostrar a emersăo do homem, do seu mundo natural e biológico, para o mundo da cultura e espiritual, sua morada como ser livre". Cf.: Weber T.: Hegel: liberdade, estado e histónia, Petrópolis, 1993, p. 95.

7 Hegel, retornando aos gregos, vai recuperar o que ele denomina a dimensão objetiva da liberdade, ou, liberdade objetiva, que é o conjunto de instituiçōes e comunidades através de que a liberdade se efetiva no mundo da cultura, criado pelo ser humano. Cf.: Oliveira M. A. de, Hegel: Normatividade e Eticidade, op. cit., p. 207 e ss. 
iguais e livres, isto é, cada um é para si pela mediação do outro e se respeitam como entes que não são somente meios mas fins em si mesmos. Com isto tocamos o cerne do processo de libertação, que é a vida humana: ser homem significa conquistar-se como ser livre e o caminho para chegar aí é cada individualidade negar-se realidade isolada e construir um mundo que é efetivador da liberdade ${ }^{m}$, onde cada um existe para si enquanto existe pelo outro e para o outro, isto é, onde se constitui uma intersubjetividade simétrica que "é síntese da identidade (todos são considerados como fins em si mesmos) e da diferença(todos são conhecidos nas diferenças que não destroem a igualdade básica) ${ }^{n} .{ }^{\infty} \mathrm{A}$ subjetividade, assim, se constitui enquanto subjetividade pela mediação do encontro com a outra subjetividade, o que se faz possivel porque cada uma é presença autopresente do incondicionado, que é o espaço de possibilitação da comunhão das subjetividades. Tem razão Hegel, quando sabe que ali onde o humano se divide em senhor e escravo, não é possivel emergir a liberdade verdadeira.

A liberdade como síntese de opostos é unidade de universalidade e particularidade, o que significa dizer que a liberdade é conquistada quando o ser humano é capaz de elevar sua vida individual empírica à esfera da universalidade, "isto é, do reconhecimento mútuo da igual dignidade, a afirmação recíproca do outro como sujeito, o que não significa eliminação da individualidade, mas sua constituição como individualidade, verdadeiramente livre, que se sabe como ser único e, ao mesmo tempo, igual, isto é, aberto à comunhão das liberdades. Numa palavra, a gênese da liberdade é a gênese de uma sociabilidade solidária, enquanto reconhecimento mútuo de liberdades, o que significa dizer que a subjetividade se constitui através da comunhão de pessoas livres e iguais, ou seja, através de uma ordenação social radicada no reconhecimento universal, o que implica a eliminação de qualquer tipo de negação da subjetividade ${ }^{\text {ea }}$ e luta pela afirmação da individualidade do ser humano em sua relação com o outro enquanto construção de uma vida social radicada na solidariedade universal. ${ }^{\text {on }}$ Portanto, a liberdade se

* Hegel considera o trabalho o elemento mediador deste processo. Cf.: Oliveira M. A de, A dialética do senhor e do escravo: a parábola do processo de humanização enquanto processo de libertaçăo, in: Etica e Sociabilidade, op. cit., p. 192 e ss.

$\infty$ Cf.: Oliveira M. A de, Desafios éticos da globalização, in: Consecratio Mundi, Festschrift em homenagem a Urbano Zilles, ed. por Ulmann R. A., Porto Alegre, 1998, p. 523.

${ }^{81}$ Nesta perspectiva Hegel ataca o formalismo kantiano caracterizado pela contraposiçăo entre vontade universal (forma) e vontade individual (conteúdo). Cf.: Weber T., Ética e Fllosofia Polltica: Hegel e o Formalismo kantiano, Porto Alegre, 1999, p. 59: "Um princípio ético, segundo Hegel, é resultante da determinação e mediação das vontades livres dos sujeitos agentes. Constitui-se de historicidade e temporalidade. Implica, portanto, forma e conteúdo. Ou seja, um conteúdo também é universalizável". No entanto, pode-se e deve-se falar, também, de um a priori material e não somente de uma dimensāo apriónica e de uma dimensão empírica na ética. Cf.: Hösle V., Moral und Politik, op. cit., p. 154 e ss.

2 Cf.: Oliveira M. A. de, Leitura hegeliana da revolução francesa, op. cit., p. 232: "Trata-se, sempre de novo, de refazer o processo através do qual o individuo singular pela mediação da participação no "logos universal", gesta-se como individuo universal, rompendo o isolamento em sua vida e abrindo-se ao processo universal de reconhecimento da dignidade das liberdades".

๓ Por esta, para Hegel, o solipsismo, que caracteriza a postura moderna, é destruidor da subjetividade. Cf.: Oliveira M. A. de, A dialética do senhor e do escravo, op. cit., p. 194.

* Cf.: Rosenfield D., Politica e Liberdade em Hegel, São Paulo, 1983, p. 143: "... a segunda natureza do homem é a história ética do indivíduo, isto é, a história do movimento ativo dos indivíduos chegando à consciência de si mesmos como membros de uma comunidade". 
gesta, em última instância, na esfera da intersubjetividade ${ }^{65}$ através da configuração de formas simétricas de relacionamento que possam garantir a autonomia de todos. Liberdade plena é liberdade historicizada, mundificada, exteriorizada em instituiçōes, que regulam as relações constitutivas do ser humano enquanto ser humano e, assim, se manifestam como mediações históricas inelimináveis no processo de conquista da liberdade.

M. Mülles ${ }^{s}$ denomina o produto visivel de uma ação comum nas contingências históricas, aquela configuração que regula a convivência entre os sujeitos de "instituição" de tal modo que podemos dizer ser a instituição a sintese entre transcendência e engajamento e a instituição, que perpassa todas elas como regra fundamental de sua configuração numa situação histórica específica é, na linguagem da tradição, o direito que assim só pode ser entendido como uma instituição da liberdade, ou seja, como a instituição, cuja função específica é abrir o espaço para a efetivação da liberdade. Daí porque a dupla raiz do direito: por um lado, a liberdade e seus princípios e, por outra, a histónia.

Os princípios da liberdade só se efetivam na medida em que produzem diferentes configuraçōes do direito nas diferentes situações históricas. Nesta perspectiva, os princípios da liberdade constituem o horizonte normativo das produções históricas que podem não efetivar liberdade. Aquilo que a tradição ocidental chama de direito positivo é a formulação expressa da constitucionalidade do agir comunitário de uma sociedade livre. Mas o direito positivo pode ser falso: ele pode se contrapor à consciência de liberdade já historicamente conquistada. Por isto, a partir do direito fundamental, enquanto direito da liberdade, que a tradição chamou de direito natural," pode-se e deve-se resistir às normas jurídicas formuladas no direito positivo e protegidas pelo poder do Estado na medida em que elas constituem obstáculos à efetivação da liberdade, já que sua função fundamental é exprimir a liberdade, que constitui o ser humano enquanto ser humano, a nível da convivência histórica das pessoas, isto é, no nível da finitude, da limitação, das relações intersubjetivas, das chances abertas pela história para a organização racional da vida em comum, como dizia Hegel, na esfera do mundo da cultura, do espírito objetivo de tal modo que possa ocorrer a unidade entre subjetividade (indivíduo livre) e objetividade (intersubjetividade igualitária), que constitui a liberdade em seu sentido pleno, liberdade concreta, subjetiva e objetiva. Com isto se revela que a liberdade só é real enquanto unidade de todas estas liberdades, portanto, como sintese de opostos.

w Hegel desloca o processo de constituição da subjetividade da esfera da interioridade, que havia constituido o horizonte de pensamento da modernidade, para a esfera do mundo intersubjetivo. Cf.: Oliveira M. A. de, Seculanização e Ética, in: Ética e Práxis Histónica, São Paulo, 1995, p. 125-126.

* Cf.: Müller M., Philosophische Anthropologie, op. cit., p. 187. Cf. também: Schelsky H. (ed.), Zur Theorie der Institution, Düsseldorf, 1970, p. 10 e ss.

* O conceito de direito natural é um conceito normativo, portanto, diz respeito ao fundamento de validade das normas que regem as relaçōes sociais. Direito natural, nesta perspectiva, é aquele conjunto de normas que, por razões éticas, se pode exigir através de sanções. Neste sentido, o direito natural é a medida para o julgamento do caráter ético do direito positivo Cf: Hösle V., Moral und Politik, op. cit., p. 777 e ss. 